\title{
How Guest Delight Affected Hotel Pricing before and during Covid-19 Pandemic
}

\author{
Domagoj Nikolić, Lecturer \\ Rochester Institute of Technology Croatia \\ domagoj.nikolic@croatia.rit.edu
}

\author{
Andrea Mitrović, Graduated Student \\ Rochester Institute of Technology Croatia \\ axm8068@g.rit.edu
}

Purpose: This study aimed to establish the extent to which Dubrovnik upscale hotels delight their guests and if such "wow effects" affect their rates.

\begin{abstract}
Study design/methodology/approach: TripAdvisor pages of 15 Dubrovnik upscale hotels were searched for guest delight attributes and hotel rates and analysed with descriptive statistics, linlog regression, and Spearman correlation.
\end{abstract}

Findings: Dubrovnik's upscale hotels provide reliable services but still lack the "wow effect". In this context, guest delight has no discernible effect on hotel rates. Hotels should focus more on personalization and guest delight in their search for extractable value, particularly during the Covid-19 pandemic characterized by diminished occupancy and rates.

Originality: Although guest delight was studied relatively extensively, this is the first time it was done in relation to hotel rates.

Keywords: guest delight, hotel pricing, price determinants, experience personalization, Dubrovnik

\section{Introduction}

\section{Upscale guests must be delighted}

Since the end of the 1990s, it has been known that companies must reach beyond services into experiences in their quest for extractable value (Pine \& Gilmore, 1998). The hospitality industry, which is undoubtedly dependent on guest experiences, should pay close attention to the expectation/perception gap (Padma \& Jiseon, 2020). This gap is not only present in the budget segment but paradoxically gets wider with upmarket hotels that often do not deliver the expected value to their guests (Semler, 2015). For example, when an ultra-luxury hotel company conducted a study of their guests' experiences in London and Paris, it found that guests saw no differentiation between luxury hotels regardless of the brand (Brant, 2020). This implied a lack of character and limited personalization (Harkison, 2018), which reduces hotel offer to standardized services (Pine \& Gilmore, 1999). Since services without enchantments are nowadays commoditized, this becomes both a pricing and occupancy issue (Brant, 2020). As hotels struggle to attract and gain the loyalty of informed and networked customers in the highly competitive global market, experience personalization exceeding satisfaction by producing delight becomes a must (Andreassen et al., 2016; Vanhamme, 2008; St-James \& Taylor, 2004).

\section{What is personalization}

Personalization can be defined as the customization of services to specific guest wants and the process of providing such uniquely tailored services (Vesanen, 2007). Personalization places individual guests in the centre is principally value-driven, and once achieved, should be further innovated, improved, and combined with new service components (Nasution \& Mavondo, 2007). In upscale hotels, personalization is driven by specific and changing guest-context and 
aimed at producing additional excitement (Johnson, 2006). Hotel operations, therefore, can not be based just on SOPs; they must be complemented with functional components transforming services into experiences. This presumes that hotel staff must be empowered to discover unique guest contexts and characteristics, which can be done by adding technology, establishing communication, and building relationships (Weinstein, 2017).

Since experience personalization is never external of the guest, companies must engage customers to co-create and 'experiment' with services, which inspires emotions, builds loyalty, and ensures repeated business (Fu, Lehto, \& Torres, 2014). Empathic staff is indispensable in creating emotional bonds and relationships and, if the guests are not engaged on that level, they will not be satisfied (Wu \& Yuhui, 2019).

\section{What is customer experience?}

Customer experience is integral to personalization and can be defined as a dynamic, individual, and proactive relationship between the employee and the customer (Harkison, 2018). Hotel experience has additional components, as guests are engaged consciously and subconsciously during their stay by developing intellectual, physical, emotional, and spiritual impressions. Customer experience is an assessed process taking place directly and indirectly with the hotel and is directly related to customer value (Ada \& Au Young, 2020). Co-creation aims to create authenticity - the impression that service is delivered straight from the heart. Comfort combined with personalized experiences supports guest satisfaction and creates additional value in upmarket hotels (Ariffin, Maghzi, Soon, \& Alam, 2018)

\section{Co-creation of unique customer value}

When customers engage in value-creation, they gain additional knowledge and awareness and can self-customize features, which ensures that they get their own unique value (Prahalad \& Ramaswamy, 2004). Therefore, a unique customer value-creation process is a partnership that cannot exist without involving the guest in the process of service design (Sjodin, 2012). For customers, convenience is essential, which means that the co-creation process must be effortless and seamless (Wu \& Yuhui, 2019). Guests automatically want to be involved in cocreation because they can see benefits on multiple levels: hedonic (enjoyable and unforgettable), cognitive (control of information and knowledge), social (engagement with different people), personal (reliable recognition), pragmatic (avoiding inappropriate services) and economic (material recognition of their effort). Once these six dimensions are recognized and fulfilled, the expected experience turns into a positive guest-hotel relationship and loyalty (Verleye, 2015).

\section{Expectation/perception gap}

Parasuraman, Zeithaml \& Berry (1991) highlighted that companies could be drowning in measurement, short-term financial performance, productivity, and efficiency while neglecting the fundamental question of "How do customers see us?" The lacking focus on customer satisfaction and value puts businesses at a long-term danger because of the multi-levelled gap that such limited focus opens between the company management and reality. A vital element of this rift is the gap between customer expectations and customer perception, which sometimes can be totally unrecognized by hotel companies.

The expected experience is a recollection of guests' past experiences and the related information received. At the same time, the perception revolves around the guest's assessment of the service and the impression created about the hotel during the stay (Barrett \& Baldry, 2003). The expected level of service also influences perception and subjective traits, e.g., 
individual needs and wants and, if the promised experience is not fulfilled, this will result in a diminished value and guest dissatisfaction (Verleye, 2015; Fu, Lehto, \& Torres, 2014; Torres \& Kline, 2006).

\section{Employee empowerment and customer delight}

Empowering employees is a priority for experience personalization because by training and allowing the personnel to establish relationships and custom-tailor the services, the hotel creates knowledge of problems and successful interventions while simultaneously creating additional customer value (Padma \& Jiseon, 2020). Solving customer problems, preferably during the first contact, results in service recovery and increased guest loyalty. The organization, therefore, must invest in employees' constant training, education, and development (Torres \& Kline, 2006). To successfully perform at a high level, the hotel staff must be emphatic, creative, enterprising, competent, helpful, and qualified. Since employee's wellbeing and grooming are essential to this end, fair pay, a clean environment, and good relationships at the workplace are crucial (Torres \& Kline, 2013).

To complicate things further, hotels are no longer seen only as convenient places to stay, because nowadays guests want to be delighted. Customer delight is a factor of exceeding customer expectations, resulting in emotional engagement combining joy, thrill, and surprise, which strongly influences customer loyalty (Fu, Lehto, \& Torres, 2014).

Torres' and Kline's (2013) studied 105 guest letters to find the critical hotel guest delight attributes: taking care of customer's needs, exceptional friendliness, staff's professionalism, going the extra mile for delivering a service, problem-solving skills, and extraordinary food and beverage. Amenities, such as a great lobby, superior pool, and entertaining facilities, employee use of the guest's name, desire to delight, and creativity at delivering service, were ranked lower by the guests. This would imply that a relatively large number of intangibles come before tangibles, which means that tangible attributes are now seen as standard and expected. Further in their study, the authors came up with the customer delight typology presented in Table 1.

\begin{tabular}{ll}
$\begin{array}{l}\text { Table 1: Customer Delight Typology } \\
\text { Problem resolution } \\
\text { delight }\end{array}$ & $\begin{array}{l}\text { Solving the problem as quickly as possible. Solving problems outside the hotel } \\
\text { will extra please the guest, i.e., fixing luggage problems with the airline, } \\
\text { lending the guest a clean shirt, cleaning the ice of the guest's car from the } \\
\text { snowstorm. Personnel must be trained and empowered to think outside of the } \\
\text { box. }\end{array}$ \\
\hline Professional delight & $\begin{array}{l}\text { Staff to be supported, motivated, knowledgeable and prepared, including a } \\
\text { positive attitude, sophisticated skillset including "soft" skills, and non- } \\
\text { intrusive handlining of guests' needs. }\end{array}$ \\
\hline Comparative delight & $\begin{array}{l}\text { Guests are aware of other hotels and always compare one with another. That } \\
\text { way they can understand if they got the superior service or not. This is } \\
\text { primarily noticeable in the post-purchase evaluating phase. Hotel needs to } \\
\text { know the strengths and weaknesses of their competition. }\end{array}$ \\
\hline Eharismatic delight & $\begin{array}{l}\text { Employees need to be personable, friendly, and similar traits. That is why } \\
\text { recruiting, training, and taking a personality test are essential. Employee } \\
\text { attitude has a significantly positive effect on the finished experience. }\end{array}$ \\
\hline $\begin{array}{l}\text { One should dedicate time to finding information. Guests, their needs and } \\
\text { desires must be understood. Then guests feel unique and individualized and } \\
\text { appreciate the value. It is necessary to support the guests' self-esteem as best } \\
\text { as possible. }\end{array}$ \\
\hline
\end{tabular}




\section{Pricing}

Although authors, e.g., Torres \& Kline (2013) and Fu, Lehto \& Torres (2014), have researched hotel guest delight from different aspects to our knowledge, no one has explored the connection between customer delight and hotel rates. Pricing in the hotel industry is complex because hotels use different pricing strategies depending on their revenue objectives and specific strategic placement (Kasavana \& Singh, 2001). These strategies can be very flexible and include numerous factors, such as destination, hotel star rating, and overall content (Wei-Ting, Jui-Kou, \& Fei-Ching, 2010). The brand also plays an important role (Su \& Reynolds, 2017). However, in the upscale segment that we are looking at, hotels are primarily focused on valuebased factors, mainly when the demand from the high-paying demographic is steady, which maximizes the profitability prospects (Pohland \& Kesgin, 2018; Rao \& Kartono, 2009).

\section{Research Goal}

The secondary research showed that hotels in the upmarket segment must personalize guest experiences by creating unique customer value. As guest delight must be an integral part of the strategy, hotels must go beyond closing the expectation/perception gap and exceed guests' expectations.

In the primary research, we wanted to verify to what extent guest delight is present in the Dubrovnik upmarket hotels and whether there is a discernible relation of guest delight with hotel rates before and during the Covid-19 pandemic. The goal is to assess the guest-delight attributes to check whether Dubrovnik upmarket hotels qualify for luxury standard and evaluate the impact of these attributes on rates before and during the Covid-19 pandemic.

\section{Method}

The data was collected from TripAdvisor for 15 Dubrovnik upmarket hotels by using 15 selected reviews from each hotel, which gave us a total of 225 reviews. The reviews were randomly selected; every fifteenth review was evaluated and, in those cases when a hotel did not have enough reviews, every fifth. Hotels were analysed based on the attributes listed in Table 2. The first six were from the research of Torres' and Kline's (2013) typology with an added element of "Surprise" also originating from their paper. Additionally, we added the "Recommendation" attribute because hotels with a positive Word of Mouth (WoM) perform financially better regardless of their room price or star rating (Wang, Lu, Chi, \& Shi, 2015). Finally, hotel names were replaced by codes from H1 to H15 for confidentiality reasons.

Guests' reviews were analysed in terms of their positive, negative, and neutral content. Then, the data was entered into an Excel spreadsheet: if the guest left positive feedback for a particular attribute, number 2 was entered; in the case of a negative review, we entered 0 ; when the attribute was not mentioned, we entered 1 in the spreadsheet.

We used descriptive statistical analysis using average and standard deviation to evaluate the guest delight attributes and relational linear-logarithmic regression analysis to determine relationships between hotel rates and attributes. Regression is a usual statistical tool for establishing pricing determinants in hotels, although there is no general agreement on the regression type. For example, in their analysis of price, occupancy, and guest satisfaction, Mattila \& O'Neill (2003) used the linear regression model. Meanwhile, Chen, Yang, Li, \& Liu (2015) used quadratic regression in their study of guest satisfaction and occupancy. However, most of the previous research primarily relied on linlog regressions following the work of Rosen (1974), followed by Espinet et al. (2003), Thrane (2007), Chen \& Rothschild (2010), KUShl \& Caca (2010), Abrate, Fraquelli, \& Viglia, (2012) for hotel accommodation and 
Monty \& Skidmore (2003), Juaneda, Raya, \& Sastre (2011), Portolan (2013), Nikolić \& Čavar (2020) for other types of accommodation, etc.

In the end, we used Spearman's correlation to compare the ranking of hotels according to guest delight with TripAdvisor ranking to verify whether guests perceive delight as a vital factor in their evaluations (Martin-Fuentes, 2016).

Table 2: Attributes for data collection

\begin{tabular}{|c|}
\hline $\begin{array}{l}\text { roblem-Solution Delight } \\
\text { - Can employees solve guests' problem as quickly as } \\
\text { possible? } \\
\text { Do employees think out of the box in solving guests' } \\
\text { problems? }\end{array}$ \\
\hline $\begin{array}{l}\text { Professional Delight } \\
\text { - Are the employees knowledgeable? } \\
\text { - Are the employees well prepared? } \\
\text { - Do employees have a positive attitude? } \\
\text { - } \text { Are employees have a can-do attitude? } \\
\end{array}$ \\
\hline $\begin{array}{l}\text { Comparative Delight } \\
\text { - Do guests compare one hotel with another? } \\
\text { - Was the service superior? }\end{array}$ \\
\hline $\begin{array}{l}\text { Charismatic Delight } \\
\text { - Were the employees personal and friendly? }\end{array}$ \\
\hline $\begin{array}{l}\text { Fulfilment Delight } \\
\qquad \quad \text { Did employees fulfil guests' needs and desires? }\end{array}$ \\
\hline $\begin{array}{l}\text { Recommendation } \\
\bullet \quad \text { Did the guest recommend the hotel? }\end{array}$ \\
\hline $\begin{array}{l}\text { Surprise } \\
\bullet \quad \text { Did employees surprise guests in any way? }\end{array}$ \\
\hline
\end{tabular}

\section{Results}

\section{Descriptive Analysis and Average for attributes}

Descriptive analysis in Table 3 shows the mean (first row) and standard deviation (second row) for 15 Dubrovnik hotels. The table contains problem-solution (P-S), professional (Pro.), comparative (Com.), charismatic/empathic (Cha.), fulfilment (Ful.), recommendation (Rec.) and surprise (Sur.). The mean identifies whether a particular attribute was perceived as positive, negative, or neutral. The distance from 1 in the direction of 0 or 2 indicates the intensity of the guests' delight in a negative (0) or positive direction (2). Furthermore, we calculated the average (Attribute Composite Mean) for every hotel separately.

Table 3: Descriptive Analysis of Means and Standard Deviations

\begin{tabular}{|c|c|c|c|c|c|c|c|c|}
\hline $\begin{array}{l}\text { Hotel } \\
\text { Code }\end{array}$ & P-S. & Pro. & Com. & Cha. & Ful. & Rec. & Sur. & $\mathbf{A C M}$ \\
\hline \multirow{2}{*}{ H1 } & 0.93 & 1.46 & 1.20 & 1.33 & 1.26 & 1.33 & 1.35 & 1.27 \\
\hline & 0.45 & 0.63 & 0.56 & 0.48 & 0.45 & 0.48 & 0.42 & \\
\hline \multirow[b]{2}{*}{ H2 } & 1 & 1.33 & 1 & 1.33 & 1.2 & 1.2 & 1.06 & 1.16 \\
\hline & 0.37 & 0.61 & 0.37 & 0.61 & 0.56 & 0.41 & 0.25 & \\
\hline \multirow{2}{*}{ H3 } & 0.86 & 1.46 & 1 & 1.53 & 1.13 & 1.33 & 1,2 & 1.22 \\
\hline & 0.51 & 0.74 & 0 & 0.63 & 0.51 & 0.48 & 0.41 & \\
\hline
\end{tabular}




\begin{tabular}{|c|c|c|c|c|c|c|c|c|}
\hline \multirow{2}{*}{ H4 } & 1 & 1.73 & 1.2 & 1.53 & 1.13 & 1.26 & 1 & 1.26 \\
\hline & 0 & 0.45 & 0.41 & 0.51 & 0.35 & 0.45 & 0 & \\
\hline \multirow{2}{*}{ H5 } & 0.93 & 0.8 & 1.07 & 1.4 & 1 & 1.2 & 1 & 1.06 \\
\hline & 0.25 & 0.56 & 0.25 & 0.63 & 0.37 & 0.41 & 0 & \\
\hline \multirow{2}{*}{ H6 } & 1.2 & 1.33 & 1 & 1.4 & 1.33 & 1 & 1.07 & 1.19 \\
\hline & 0.41 & 0.72 & 0.37 & 0.5 & 0.61 & 0.37 & 0.25 & \\
\hline \multirow{2}{*}{ H7 } & 1 & 1.4 & 1 & 1.27 & 1.13 & 1.33 & 1.13 & 1.18 \\
\hline & 0.37 & 0.73 & 0.37 & 0.59 & 0.51 & 0.48 & 0.35 & \\
\hline \multirow{2}{*}{$\mathrm{H} 8$} & 1.07 & 1.53 & 1.07 & 1.6 & 1.13 & 1.2 & 1 & 1.23 \\
\hline & 0.45 & 0.74 & 0.25 & 0.63 & 0.51 & 0.56 & 0 & \\
\hline \multirow{2}{*}{ H9 } & 1.07 & 1.8 & 1.2 & 1.47 & 1.27 & 1.13 & 1.07 & 1.29 \\
\hline & 0.25 & 0.41 & 0.41 & 0.51 & 0.45 & 0.35 & 0.25 & \\
\hline \multirow{2}{*}{ H10 } & 1 & 1.4 & 1 & 1.6 & 1.2 & 1.33 & 1 & 1.22 \\
\hline & 0 & 0.5 & 0.37 & 0.5 & 0,41 & 0,48 & 0 & \\
\hline \multirow{2}{*}{ H11 } & 1 & 1.73 & 1.07 & 1.4 & 1.33 & 1.47 & 1 & 1.29 \\
\hline & 0 & 0.45 & 0.25 & 0.5 & 0.48 & 0.51 & 0 & \\
\hline \multirow{2}{*}{ H12 } & 1 & 1.47 & 1 & 1.53 & 1.27 & 1.6 & 1.13 & 1.29 \\
\hline & 0 & 0.63 & 0 & 0.51 & 0.45 & 0.5 & 0.35 & \\
\hline \multirow{2}{*}{ H13 } & 1 & 1.67 & 1 & 1.47 & 1.13 & 1.07 & 1 & 1.19 \\
\hline & 0 & 0.48 & 0 & 0.51 & 0.35 & 0.25 & 0 & \\
\hline \multirow{2}{*}{ H14 } & 1 & 1.4 & 1.07 & 1.47 & 1.13 & 1.27 & 1 & 1.20 \\
\hline & 0 & 0.73 & 0.25 & 0.51 & 0.35 & 0.45 & 0 & \\
\hline \multirow{2}{*}{ H15 } & 1.07 & 1.4 & 1.13 & 1.47 & 1 & 1.27 & 1.07 & 1.20 \\
\hline & 0.25 & 0.73 & 0.35 & 0.51 & 0 & 0.45 & 0.25 & \\
\hline$\overline{\text { ALL }}$ & $\begin{array}{ll}1.01 \\
\end{array}$ & 1.46 & 1.07 & 1.46 & 1.18 & 1.27 & 1.06 & 1.21 \\
\hline HOTELS & 0.29 & 0.64 & 0.32 & 0.51 & 0.44 & 0.46 & 0.46 & 0.06 \\
\hline
\end{tabular}

In the end, we calculated the mean of all means $=1.21$ in order to give us a global view into the guest delight in Dubrovnik upscale hotels.

\section{Pricing strategies}

Prices for before and after COVID-19 are presented in Table 4. Additionally, the table gives the ranking that we have performed based on our analysis of guest delight and an additional ranking extracted from TripAdvisor for all hotels except two (H7 and H10). These two are not in Dubrovnik and therefore do not appear in the same TripAdvisor ranking.

Table 4: Average upscale hotels prices in DBK before \& during Covid-19 pandemic in the order of guest delight ranking and compare with TripAdvisor ranking

\begin{tabular}{|l|l|l|l|l|l|}
\hline Hotel Code & $\begin{array}{l}\text { During } \\
\text { Covid-19 }\end{array}$ & $\begin{array}{l}\text { Before Covid- } \\
\mathbf{1 9}\end{array}$ & $\begin{array}{l}\text { Difference } \\
\mathbf{( \% )}\end{array}$ & $\begin{array}{l}\text { Delight } \\
\text { Ranking }\end{array}$ & $\begin{array}{l}\text { TA } \\
\text { Ranking }\end{array}$ \\
\hline H11 & 115.00 & 247.00 & $-53 \%$ & 1 & 1 \\
\hline H9 & 886.00 & 987.00 & $-10 \%$ & 1 & 25 \\
\hline H12 & 183.00 & $/$ & $/$ & 1 & 14 \\
\hline H1 & 150.00 & 283.00 & $-47 \%$ & 2 & 4 \\
\hline H4 & 491.00 & 556.00 & $-12 \%$ & 3 & 6 \\
\hline H8 & 127.00 & 175.00 & $-27 \%$ & 4 & 12 \\
\hline H10 & 253.00 & $/$ & $/$ & 5 & Not ranked \\
\hline H3 & 143.00 & 182.00 & $-21 \%$ & 5 & 16 \\
\hline H15 & 160.00 & 238.00 & $-33 \%$ & 6 & 13 \\
\hline H6 & 159.00 & 274.00 & $-42 \%$ & 7 & 5 \\
\hline H13 & 128.00 & 221.00 & $-42 \%$ & 7 & 11 \\
\hline H14 & 137.00 & 180.00 & $-24 \%$ & 7 & 9 \\
\hline H7 & 113.00 & 127.00 & $-11 \%$ & 8 & Not ranked \\
\hline H2 & 118.00 & 215.00 & $-45 \%$ & 9 & 7 \\
\hline H5 & 255.00 & 296.00 & -14 & 10 & 3 \\
\hline
\end{tabular}




\begin{tabular}{|l|l|l|l|}
\hline AVERAGE & 227.87 & 306.23 & $-29 \%$ \\
\cline { 1 - 3 } MEDIAN & 150.00 & 238.00 & $-27 \%$ \\
\cline { 1 - 3 }
\end{tabular}

\section{Regression analysis of before and during Covid-19 pandemic prices}

Table 5 explains the attributes, and Table 6 shows the regression analysis establishing a relationship between the seven mentioned attributes and prices before and during the Covid19 pandemic.

Table 5: Description of variables used in delight regression

\begin{tabular}{|l|l|}
\hline Variable & Description of variable \\
\hline Dependent variables & \\
\hline Price & Rate per night in \$ from 2021. \\
\hline LOGPRICE & Price, logged \\
\hline Explanatory variable & $\begin{array}{l}\text { Solving problems as quick as possible and } \\
\text { efficiently }\end{array}$ \\
\hline Problem- Solution & $\begin{array}{l}\text { The employee should be knowledgeable, well prepared, and } \\
\text { positive attitude. }\end{array}$ \\
\hline Professional & \begin{tabular}{l} 
Did guests get superior service? \\
\hline Comparative
\end{tabular} \\
\hline Charismatic & Employee attitude \\
\hline Fulfilment & Exceeding guests' expectation by surprising them \\
\hline Surprise & Did guests recommend the hotel? \\
\hline Recommended &
\end{tabular}

Table 6: Guest delight - price linlog analysis for Dubrovnik hotels before Covid-19

\begin{tabular}{|l|l|l|l|l|}
\hline Attribute & Coefficient & Std. Error & tStat & P-value \\
\hline Prob.- Solution & -2.135265328 & 1.942720006 & -1.099111205 & 0.321803196 \\
\hline Professional & 0.299263171 & 0.685609997 & 0.436491843 & 0.68068486 \\
\hline Comparative & 5.098247295 & 1.625757041 & 3.135922015 & 0.025784614 \\
\hline Charismatic & -0.268522535 & 1.262374509 & -0.21271226 & 0.839951713 \\
\hline Fulfilment & 0.949872926 & 1.82481506 & 0.520531065 & 0.624913483 \\
\hline Surprise & -1.127208969 & 1.556119178 & -0.724371877 & 0.501301648 \\
\hline Recommended & -2.268692723 & 1.286870784 & -1.762953011 & 0.138196543 \\
\hline Adj. R-squared & 0.222118789 & Significance F & 0.225674133 & \\
\cline { 1 - 3 }
\end{tabular}

Table 7: Guest delight price linlog analysis for Dubrovnik hotels during Covid-19

\begin{tabular}{|l|l|l|l|l|}
\hline Attribute & Coefficient & Std. Error & tStat & P-value \\
\hline Prob.- Solution & -2.284538281 & 3.057842213 & -0.747107967 & 0.479336397 \\
\hline Professional & 0.013481295 & 1.024216914 & 0.013162539 & 0.989865404 \\
\hline Comparative & 3.613646182 & 2.225663724 & 1.623626311 & 0.148484507 \\
\hline Charismatic & 1.204328586 & 1.685234099 & 0.714635781 & 0.497967406 \\
\hline Fulfilment & 0.766450216 & 2.703325223 & 0.283521276 & 0.784979376 \\
\hline Surprise & -1.891285546 & 2.250009311 & -0.840567875 & 0.428364492 \\
\hline Recommended & -1.084161309 & 1.74831318 & -0.620118479 & 0.55482185 \\
\hline Adj. R-squared & -0.323120018 & Significance F & 0.691519466 & \multicolumn{2}{|l}{} \\
\cline { 1 - 3 }
\end{tabular}

Table 8: TA ranking price linlog analysis for Dubrovnik hotels before Covid-19

\begin{tabular}{|l|l|l|l|l|}
\hline Ind. Variable & Coefficient & Std. Error & tStat & P-value \\
\hline TA Ranking & 5.319447024 & 0.872770171 & 6.094900123 & $7.79368 \mathrm{E}-05$ \\
\hline Adj. R-squared & -0.082988987 & Significance F & 0.781962334 & \multicolumn{1}{|c}{} \\
\cline { 1 - 3 } & &
\end{tabular}

Table 9: TA ranking price linlog analysis for Dubrovnik hotels after Covid-19

\begin{tabular}{|l|l|l|l|l|}
\hline Ind. Variable & Coefficient & Std. Error & tStat & P-value \\
\hline TA Ranking & 4.733929404 & 0.94153239 & 5.027898618 & 0.000231281 \\
\hline Adj. R-squared & -0.055028474 & Significance F & 0.6122061 & \multicolumn{1}{|c|}{} \\
\cline { 1 - 3 }
\end{tabular}

Spearman's correlation between the Delight Ranking and TA Rankings $=-0.043039668$ established that there is almost no correlation between the two. 


\section{Discussion}

The research aimed to verify guest delight in upscale hotels in Dubrovnik and whether it affects their rates. We observed that guests notice staff professionalism and empathy the most (Pro, Char.=1.46). However, whether this is owed to Dubrovnik's long tradition in tourism generating a specific service mentality or company policies and training is debatable and was not determined by this research. Nevertheless, since on the scale from 1 (neutral) to 2 (delighted), the results are close to the midpoint, a bit removed to neutral, it would be fair to say that the guests are moderately delighted with these attributes.

Willingness to recommend (Rec.=1.27) and fulfilment of guests' needs (Ful.=1.18) are less present but still positive. In this regard, Dubrovnik hotels close the expectation/perception gap successfully, while guest expectations are not frequently exceeded.

Factors directly related to staff empowerment, such as problem-solving and creating surprises, are almost entirely neutral ( $\mathrm{P}-\mathrm{S}=1.01$, Sur.=1.06). Therefore, it is not surprising that guest sees little differentiation in Dubrovnik upscale hotels $(\mathrm{Comp} .=1.07)$, which is also corroborated by the minimal standard deviation between the attribute cumulative means for all hotels $(\mathrm{SD}=0.06)$.

The mean of all means of guest delight (=1.21) leaning more to "neutral" (1) than "delighted" (2) also leads us to conclude that Dubrovnik upscale hotels provide solid service but should work on a stronger "wow effect" delighting the guest. In other words, personalized experiences are not very present in the observed Dubrovnik hotels, and therefore, they, regardless of their facilities and other unobserved attributes, do not qualify for the rank of luxury, because, in the luxury segment, service without context is nothing (Brant, 2021).

Our analysis also showed that delight factors do not affect differences in hotel rates. This, in turn, tells us that some other unobserved factors significantly impact the price, e. g. location, interior design, F\&B offer, cleanliness, functionality, destination's, brand, etc. (Jinwon, Seongsoo, Sanghoon, \& SeungHyun, 2020; Soler \& German, 2018; Honglei, Zhang, Shaojing, Shaowen, \& Jinhe, 2011) and those pricing strategies are probably driven by maximization of profits (Pohland \& Kesgin, 2018). To corroborate this interpretation with an additional argument, we also established that the TripAdvisor ranking of hotels, which exceeds parameters of customer delight, showed a solid connection to price. We also confirmed that our Delight Ranking was not correlated with the TripAdvisor Ranking, which further underlines our finding that many other deciding factors determine overall hotels' WoM and rates other than guest delight.

It would appear that, in the pre-Covid-19 situation, characterized with strong demand generated by the sending marketing with considerable spending power and supported by the strong Dubrovnik brand and solid infrastructure, Dubrovnik upscale hotels did not have to focus very much on the guest delight to reap healthy profits. Since the hotel rates in Dubrovnik dropped $29 \%$ on average during the Covid-19 pandemic, and no discernible connection of price to customer delight in the situation of diminished occupancy was available, the potential strongest influencers were the power of the Dubrovnik brand (popularity of destination), (un)favourable socio-economic conditions at the sending markets and financial objectives set by the owners. Therefore, it would appear that, before Covid-19, the strong demand had a positive effect on hotels and that, during Covid-19, the diminished demand has a relatively strong negative impact. However, when we compare the prices drop in upscale hotels in Dubrovnik $(29 \%)$ compared with Bangkok (51.7\%), Dubai (46.4\%), London (34.2\%), New York (37.1\%), Hong Kong (34.9\%), Tokyo (41.2\%) and Vienna (47.5\%), we can see that negatives effects of the 
pandemic to hotels in Dubrovnik were comparatively smaller, but whether this is realistic and sustainable remains to be seen (Martinović, 2021).

As the industry was not adequately prepared for a disaster situation such as Covid-19 (AboMurad, Al-Khrabsheh, \& Jamil, 2019), hotels faced diminished demand, changing customer needs, and weak liquidity (Kukanja, Planinc, \& Sikošek, 2020), particularly in Europe where the most negative impacts have been reported (Napierala, Leniewska-Napierala, \& Burski, 2020). During the 2008 economic downturn, hotels downgraded their rates to increase occupancy, leading to even more inadequate revenues (Chih-Chien, 2009). The COVID-19 should be seen as a crisis of opportunity for developing other new competitive advantages (Hao, Xiao, \& Chon, 2020) because hotels are focusing on high quality, brand value, and loyal customer base are in a stronger position to weather the crisis and invent new ways to secure long-term value both for their customers and themselves (Alonso-Almeida \& Bremsera, 2013).

Therefore, we would strongly encourage upscale hotels in Dubrovnik to work on the experiential components of their offer to strengthen differentiation, improve rates, boost loyalty and thus generate additional demand, because upmarket hotels lacking customer delight are known to run a problem of negative guest satisfaction (Chen, Yang, Li, \& Liu, 2015; Mattila $\left.\& O^{\prime} N e i l 1,2003\right)$. In addition, hotels with a higher rating can charge more (Castro, Ferreira, \& Ferreira, 2016). We would also speculate that the lacking customer delight affects hotel rates and repeated business in Dubrovnik negatively even during the intense demand periods because delighted guests show more significant commitment, loyalty, and repeat business (Barnes, Collier, Howe, \& Hoffman, 2016; Barnes, Beauchamp, \& Webster, 2010). Therefore, Dubrovnik upmarket hotels should design customer-centred experience personalization processes to strengthen guest delight (Parasuraman, Ball, Aksoy, Keiningham, \& Zaki, 2020; Field et al., 2018; Cook et al., 2002). In such a way, they would improve their own and the destination's brand, which should, in turn, both have a long-term positive effect on the Dubrovnik REVPAR.

The contribution of this research is that, although many authors to date researched guest delight, no one to our knowledge tried to establish its connection to hotel rates (Goswami \& Sarma, 2019; Torres, Fu, \& Lehto, 2014; Torres \& Kline, 2013; Crotts, Pan, \& Raschid, 2008; Torres \& Kline, 2006). The results are pretty telling but still inconclusive and definitely require further research in specific contexts because we realize that in high-end hospitality, customer delight does not always result in customer loyalty (Bowden \& Dagger, 2011).

This research also had its limitations. Firstly, we picked a limited number of random reviews, which prevented us from capturing the absolutely whole picture. Furthermore, it is also possible that TripAdvisor reviewers do not always describe the full extent of their experience. Additionally, in our research of hotel rates prices before the Covid-19 pandemic, we were only able to find the rates of 13 out of 15 hotels. Lastly, our study was focused on the specific situation in Dubrovnik and should be expanded to other international destinations.

\section{References}

Alonso-Almeida, M., \& Bremsera, K. (2013). Strategic responses of the Spanish hospitality sector to the financial crisis. International Journal of Hospitality Management, 32, 141-148.

Abo-Murad, M., Al-Khrabsheh, A., \& Jamil, R. (2019). Effect of the Organisational Culture on Crisis Management in Hotel Industry: A Qualitative Exploration. International Journal of Entrepreneurship, 23(2) 1-18.

Abrate, G., Fraquelli, G., \& Viglia, G. (2012). Dynamic pricing strategies: Evidence from European hotels. International Journal of Hospitality Management, 31(1), 160-168.

Ada, L., \& Au Young, M. (2020). Brand prestige and affordable luxury: The role of hotel guest experience. Journal of Vacation Marketing, 26(2) 247-267. 
Andreassen, T. W., Kristensson, P., Lervik-Olsen, L., Parasuraman, A., McColl-Kennedy, J. R., Edvardsson, B., \& Colurcio, M. (2016). Linking service design to value creation and service research. Journal of Service Management, 27(1), 21-29.

Ariffin, A. M., Maghzi, A., Soon, J. L., \& Alam, S. S. (2018). Exploring the Influence of Hospitality on Guest Satisfaction in Luxury Hotel Services. e-Review of Tourism Research, 15(1).

Barnes, D. C., Beauchamp, M. B., \& Webster, C. (2010). To delight, or not to delight? This is the question service firms must address. Journal of Marketing Theory and Practice, 18(3), 275-284.

Barnes, D. C., Collier, J. E., Howe, V., \& Hoffman, K. D. (2016). Multiple paths to customer delight: the impact of effort, expertise, and tangibles on joy and surprise. Journal of Services Marketing, 30(3), 277-289.

Barrett, P., \& Baldry, D. (2003). Facilities Management Towards Best Practice. Blackwell Science.

Bowden, J. L., \& Dagger, T. S. (2011). To delight or not to delight? An investigation of loyalty formation in the restaurant industry. Journal of Hospitality Marketing \& Management, 20(5), 501-524.

Brant, A. (2020, November 5). Luxury Guest Experience Innovation. (D. Nikolić, Interviewer, RIT Croatia Luxury Service Excellence class materials)

Brant, A. (2021, January 19). In conversation with Ana Brant. (A. Manson, Interviewer) Joblux. Retrieved April 27, 2021, from https://joblux.com/dorchester-client-experience/

Brant, A. (n.d.). Ana Brant's Seven Blocks of Luxury. Dubrovnik: RIT Croatia.

Buhej, M., Costa Cunha, K., Beka, G., Mavrić, B., Carmo de Souza, Y., Costa Silva, S., . . Yein, T. (2020). The Extent of COVID-19 Pandemic Socio-Economic Impact on Global Poverty. A Global Integrative Multidisciplinary Review.

Chen, C.-F., \& Rothschild, R. (2010). An application of hedonic pricing analysis to the case of hotel rooms in Taipei. Tourism Economics, 16(3), 685-694.

Chen, C.-M., Yang, H.-W., Li, E. Y., \& Liu, C.-C. (2015). How does hotel pricing influence guest satisfaction by the moderating influence of room occupancy? International Journal of Hospitality Management, 49, 136138.

Chih-Chien, C. (2009). What revenue-optimizing firms can do about their deal-seeking consumers: The role of price patterns, timing and cancellation policies in travelers' advanced booking decisions. University of Illinois at Urbana-Champaign.

Cook, L. S., Bowen, D. E., Chase, R. B., Dasu, S., Stewart, D. M., \& Tansik, D. A. (2002). Human issues in service design. Journal of operations management, 20(2), 159-174.

Crotts, J. C., Pan, B., \& Raschid, A. E. (2008). A survey method for identifying key drivers of guest delight. International Journal of Contemporary Hospitality Management, 20(4), 462-470.

Espinet, J. M., Saez, M., Coenders, G., \& Fluvia, M. (2003). Effect on prices of the attributes of holiday hotels: a hedonic prices approach. Tourism Economics, 9(2), 165-177.

Field, J. M., Victorino, L., Buell, R. W., Dixon, M. J., Goldstein, S. M., Menor, L. J., . . Zhang, J. J. (2018). Service operations: what's next? Journal of Service Management, 29(1), 55-97.

Fu, X., Lehto, X., \& Torres, E. (2014). Examining key drivers of customer delight in a hotel experience: A crosscultural perspective. International Journal of Hospitality Management.

Goswami, S., \& Sarma, M. K. (2019). Modelling customer delight in hotel industry. Global Business Review, 20(2), 405-419.

Hao, F., Xiao, Q., \& Chon, K. (2020). COVID-19 and China's Hotel Industry: Impacts, a Disaster Management Framework, and Post-Pandemic Agenda. International journal of hospitality management, 90, 102636.

Harkison, T. (2018). The use of co-creation within luxury accommodation experience - myth or reality. International Journal of Hospitality Management, 71, 11-18.

Honglei, Z., Zhang, J., Shaojing, L., Shaowen, C., \& Jinhe, Z. (2011). Modeling hotel room price with geographically weighted regression. International Journal of Hospitality Management, 30(4), 1036-1043.

Hung, W.-T., Shang, J.-K., \& Wang, F.-C. (2010). Pricing determinants in the hotel industry: Quantile regression analysis, International Journal of hospitality management, 29(3), 378-384

Jinwon, K., Seongsoo, J., Sanghoon, K., \& SeungHyun, K. (2020). Why are hotel room prices different? Exploring spatially varying relationships between room price and hotel attributes. Journal of Business Research, 107, 118-129.

Johnson, A. (2006, February 7). Hotels Take 'Know Your Customer' to New Level. The Wall Street Journal. New York, USA.

Juaneda, C., Raya, J. M., \& Sastre, F. (2011). Tourism Economics. Pricing the time and location of a stay at a hotel or apartment, 17(2), 321-338.

Kasavana, L. M., \& Singh, A. J. (2001). Online Auctions Dynamic Pricing and the Lodging Industry. Journal of Hospitality \& Leisure Marketing, 9(3-4).

Kukanja, M., Planinc, T., \& Sikošek, M. (2020). Crisis Management Practices in Tourism SMEs During the Covid-19 Pandemic. Organizacija, 53(4), 346-361. 
KUShl, E., \& Caca, E. (2010). The determinants of room prices in Saranda hotels. Journal of Studies in Economics and Society, 2(1), 287-298.

Lee, B. Y., \& Park, S. (2019). The role of customer delight and customer equity for loyalty in upscale hotels. Journal of Hospitality and Tourism Management.

Martin-Fuentes, E. (2016), Are guests of the same opinion as the hotel star-rate classification system, International Journal of Hospitality and Tourism Management, 29, 126-134.

Martinović, M. (2021). Price determinants in upscale hotels during Covid-19 crisis. Senior Project. Rochester Insitute of Technology Croatia.

Mattila, A. S., \& O'Neill, J. W. (2003). Relationships between Hotel Room Pricing, Occupancy, and Guest Satisfaction: A Longitudinal Case of a Midscale Hotel in the United States. Journal of Hospitality \& Tourism Research, 27(3), 328-341.

Monty, B., \& Skidmore, M. (2003). Hedonic pricing and willingness to pay for bed and breakfast amenities in Southeast Wisconsin. Journal of Travel Research, 42(2), 195-199.

Napierala, T., Leniewska-Napierala, K., \& Burski, R. (2020). Impact of Geographic Distribution of COVID-19 Cases on Hotels Performances: Case of Polish Cities. Sustainability, 12(11).

Nasution, H. N., \& Mavondo, F. (2007). Customer value in the hotel industry: What managers believe they deliver and what customers experience. International Journal of Hospitality Management.

Nikolić, D., \& Ćavar, F. (2020). Hedonic price attributes of Airbnb listings in Split. Management, Knowledge and Learning, 20, p. 22.

Oliver, R. L., Roland T., R., \& Sajeev, V. (n.d.). Customer Delight: Foundation, Findings, and Managerial Insight. Journal of Retailing, 73(3).

Padma, P., \& Jiseon, A. (2020). Guest satisfaction \& dissatisfaction in luxury hotels: An application of big data. International Journal of Hospitality Management, 84.

Parasuraman, A., Ball, J., Aksoy, L., Keiningham, T. L., \& Zaki, M. (2020). More than a feeling? Toward a theory of customer delight. Journal of Service Management, 32(1), 1-26.

Parasuraman, A., Berry, L. L., \& Zeithaml, V. A. (1991). Perceived Service Quality as a Customer-Based Performance Measure: An Empirical Examination of Organizational Barriers Using an Extended Service Quality Model. HR Management, 30(3), 335.

Pine, J. B., \& Gilmore, J. H. (1999). The experience economy: past, present and future, In Handbook on the Experience Economy, (pp. 21-44) Northampton, USA: Edward Elgar

Pine, J. I., \& Gilmore, H. (1998). Welcome to the experience economy. Harvard business review, 76(4)(97-106).

Pohland, L., \& Kesgin, M. (2018). Pricing determinants in hotels: The case of luxury, upscale, and mid-scale price segments. Journal of Revenue and Pricing Management, 17(4), 218-230.

Portolan, A. (2013). The Impact of Private Accommodation Attributes on Tourism Demand. Dubrovnik International Economic Meeting, 1, 8-9. Retrieved from University of Dubrovnik: Department of Economy and Business Economy

Prahalad, C., \& Ramaswamy, V. (2004). Co-creation experience: the next practice in value creation. Journal of Interactive Marketing, 18(3).

Rao, V. R., \& Kartono, B. (2009). Pricing objectives and strategies: a cross-country survey. In Handbook of pricing research in marketing (pp. 9-36). Northampton: Edward Elgar.

Rosen, S. (1974). Hedonic Prices and Implicit Markets: Product Differentiation in Pure Competition. Journal of Political Economy, 82, 34-55.

Rosen, S. (1974). Hedonic prices and implicit markets: product differentiation in pure competition. Journal of political economy, 82(1), 34-55.

Semler, R. (2015, May 17). Guest-centered Hotel Managment. (J. Roevens, Interviewer)

Sjodin, C. (2012). Customers' experiences of co-creation during service innovation. International Journal of Quality and Service Sciences, 4.

Soler, I., \& German, G. (2018). Hedonic price models with geographically weighted regression: An application to hospitality. Journal of Destination Marketing \& Management, 9, 126-137.

St-James, Y., \& Taylor, S. (2004). Delight-as-magic: Refining the conceptual domain of customer delight. $A C R$ North American Advances, 31, 753-758.

$\mathrm{Su}, \mathrm{N}$., \& Reynolds, D. (2017). Effects of brand personality dimensions on consumers perceived self-image congruity and functional congruity with hotel brands. International Journal Of Hospitality Industry, 66, 112

Thrane, C. (2007). Examining the determinants of room rates for hotels: The Oslo experience. Journal of Revenue and Pricing, 4, 315-323.

Torres, E. N., \& Kline, S. (2006). From satisfaction to delight: a model for the hotel industry. International Journal of Contemporary Hospitality Management, 18(4) 290-301.

Torres, E. N., Fu, X., \& Lehto, X. (2014). Examining key drivers of customer delight in a hotel experience: A cross-cultural perspective. International Journal of Hospitality Management, 36, 255-262. 
Torres, N. E., \& Kline, S. (2013). From customer satisfaction to customer delight: Creating a new standard of service for the hotel industry. International Journal of Contemporary Hospitality Management, 25(5).

Vanhamme, J. (2008). The surprise-delight relationship revisited in the management of experience. Recherche et Applications en Marketing (English Edition), 23(3), 113-138.

Verleye, K. (2015). The co-creation experience from the customer perspective: its measurement and determinants. Journal of Service Management, 26(2) 321-342.

Vesanen, J. (2007). What is personalization? A conceptual framework. European Journal of Marketing, 41(5/6), 409-418.

Wang, M., Lu, Q., Chi, R. T., \& Shi, W. (2015). How word-of-mouth moderates room price and hotel stars for online hotel booking an empirical investigation with Expedia data. Journal of Electronic Commerce Research, 16(1), 72-80.

Weinstein, J. (2017). HOTELS Profile: Ana Brant puts service in context. Hotels Passion for Hospitality.

Wei-Ting, Y., Jui-Kou, S., \& Fei-Ching, W. (2010). Pricing determinants in the hotel industry: Quantile regression analysis. International Journal of Hospitality Management 29(3) 378 - 384.

Wu, S.-H., \& Gao, Y. (2019). Understanding emotional customer experience and co-creation behaviours in luxury hotels. International Journal of Contemporary Hospitality Management, 31(11) 4247 - 4275. 